Check for updates

New York

Cite this as: BMJ2020;370:m3046 http://dx.doi.org/10.1136/bmj.m3046 Published: 30 July 2020

\section{Covid-19: Trump is criticised for again promoting unorthodox medical information}

\author{
Janice Hopkins Tanne
}

President Donald Trump created a media storm when he retweeted a video in which Stella Immanuel, a doctor from Houston, Texas, said that hydroxychloroquine was a cure for covid-19 and that masks were unnecessary.

She was with a group called America's Frontline Doctors that included about 10 people who stood in white coats on the steps of the Supreme Court in Washington, DC.

The video was first posted by Breitbart, a right wing website, then retweeted by the president's son Donald Trump Jr and by the president. Twitter, Facebook, and YouTube soon removed it, but not before it had "gone viral" and been widely viewed by some of the president's 84 million followers. Twitter said the video was removed because it was "in violation of our covid-19 misinformation policy."

In his press briefing on 28 July the president was asked if he regretted retweeting the video. He said, "I was very impressed with her and other doctors that stood with her. I think she made sense, but I know nothing about her. She was, you know, making a statement with very respected doctors. She was not alone. She was making a statement about hydroxychloroquine with other doctors that swear by it ... I was very impressed by her. Know nothing about her. I had never seen her before. But certainly you can put her up and let her have a voice. So what they did is they took down their voice. Now, they seem to never take down the other side. They only take down conservative voices. It's a shame. And with hydroxy, all I want to do is save lives. I don't care if it's hydroxy or something else."

The reporter asked another question, noting that the doctor had mentioned a cure and had "made videos saying that doctors make medicine using DNA from aliens.” The president responded, "I know nothing about her," and walked off the stage, abruptly ending the briefing session. ${ }^{2}$

Stella Immanuel, the doctor Trump praised, is a 1990 graduate of the University of Calabar in Nigeria and has been licensed to practise in Texas since last year, where she reports that her primary specialty is paediatrics and her secondary specialty is emergency medicine. The Texas Medical Board says there are no filings, actions, or licence restrictions on her, nor any malpractice investigations. ${ }^{3}$

Immanuel is also a Christian pastor. Her church, Fire Power Deliverance Ministries, and her office, the Rehoboth Medical Center, are in a strip mall of one storey buildings in Houston, Texas.

The church's website cautions about “evil spirits” and says that “tormenting spirits are responsible for breaking marriages, hatred by earthly spouse, serious gynecological problems, marital distress, miscarriages, impotence, untold hardship, financial failure and general failure at the edge of breakthrough.” It also says, "Many women suffer from astral sex regularly. Astral sex is the ability to project one's spirit man into the victim's body and have intercourse with it. This practice is very common amongst Satanists. They leave their physical bodies in a dormant state while they project their spirits into the body of whoever they want to have sex with."4

America's Frontline Doctors seems to be a new group. According to Medpage Today, the group includes about 10 doctors, "but none of them have practices that would place them on the actual front lines of the covid-19 pandemic. Some don't currently practice at all.” 5

There is no cure for covid-19 yet. The Food and Drug Administration has cautioned against the use of hydroxychloroquine in covid-19. ${ }^{6}$ Trials have found that it does not benefit hospital patients with covid-19 and is ineffective as prophylaxis. ${ }^{7}$

Anthony Fauci, director of the National Institute of Allergy and Infectious Diseases, and Deborah Birx, the White House's coronavirus task force coordinator, have spoken strongly about the need to wear masks. Only last week the president himself endorsed wearing a mask to prevent spread of the virus, reversing an earlier stand. ${ }^{8}$

Meanwhile, US cases of covid-19 continue to climb, to 4426935 cases and 150638 deaths as at 29 July, according to the Johns Hopkins University website. ${ }^{9}$

\footnotetext{
Andrews TM, Paquette D. Trump retweeted a video with false covid-19 claims. One doctor in it has said demons cause illnesses. Washington Post. 29 Jul 2020 https://www.washingtonpost.com/technology/2020/07/28/stella-immanuel-hydroxychloroquine-video-trump-americas-frontline-doctors.

Trump continues to promote unproven drug hydroxychloroquine. CNN. https://www.cnn.com/videos/business/2020/07/28/trump-briefing-tweet-questioncollins-sitroom-bts-vpx.cnn/video/playlists/business-media.

Texas Medical Board. www.tmb.state.tx.us.

Fire Power Deliverance Ministries. https://archive.fo/firepowerministry.org.
} 
5 Basen R, D’Ambrosio A, Fiore K. No evidence that doctor group in viral video got near COVID "front lines." 29 Jul 2020. https://www.medpagetoday.com/infectiousdisease/covid19/87797.

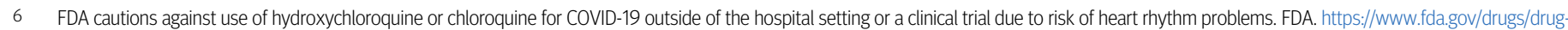
safety-and-availability/fda-cautions-against-use-hydroxychloroquine-or-chloroquine-covid-19-outside-hospital-setting-or

7 Torjesen I. Covid-19: Hydroxychloroquine does not benefit hospitalised patients, UK trial finds. BMJ 2020;369:m2263. doi: 10.1136/bmi.m2263 pmid: 32513810

8 Tanne JH. Covid-19: Trump shifts tone by endorsing masks and admitting US situation will worsen. BMJ2020;370:m2989. doi: 10.1136/bmj.m2989 pmid: 32709614

9 COVID-19 Dashboard by the Center for Systems Science and Engineering (CSSE) at Johns Hopkins University. (JHU). https://gisanddata.maps.arcgis.com/apps/opsdashboard/index.html\#/bda7594740fd40299423467b48e9ecf6.

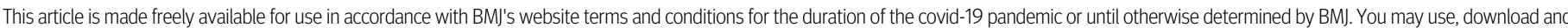
print the article for any lawful, non-commercial purpose (including text and data mining) provided that all copyright notices and trade marks are retained. 